\title{
A PILOT STUDY TO DETERMINE THE SUBSTRATE THRESHOLD FOR HEAVY METAL TOXICITY IN GROUNDCOVER PLANTS USED IN URBAN LANDSCAPES
}

\author{
JU, J. H. ${ }^{1}-$ CHOI, E. Y. ${ }^{2}-$ YoON, Y. H. ${ }^{1 *}$ \\ ${ }^{I}$ Department of Green Convergence Technology, KonKuk University, 268 Chungwondaero, \\ Chungju, Chungcheongbuk-do 27478, Republic of Korea \\ ${ }^{2}$ Department of Agricultural Sciences, Korea National Open University, 86 Daehakro, \\ Jongrogu, Seoul, 03087, Republic of Korea \\ (phone: +82-2-3668-4635) \\ *Corresponding author \\ e-mail: yonghan7204@kku.ac.kr; phone: +82-43-840-3538; fax: +82-43-851-4169
}

(Received $1^{\text {st }}$ Apr 2016; accepted $28^{\text {th }}$ Jun 2016)

\begin{abstract}
The objects of this pilot study were to determine the substrate threshold concentration for heavy metal toxicity, which is the highest permissible content in the substrates used in urban landscaping, and the maximum possible accumulation of heavy metals in shoots of Pachysandra terminalis and Vinca minor grown on substrate mixed with cadmium $(\mathrm{Cd})$, lead $(\mathrm{Pb})$, or zinc $(\mathrm{Zn})$ for 90 days. Plants were transplanted into plastic containers filled with substrate, which had been previously treated with $\mathrm{Cd}(0$, 25,50 , or $\left.100 \mathrm{mg} \cdot \mathrm{kg}^{-1}\right), \mathrm{Pb}\left(0,250,500\right.$ or $\left.1,000 \mathrm{mg} \cdot \mathrm{kg}^{-1}\right)$, and $\mathrm{Zn}\left(0,500,1,000\right.$, or $\left.2,000 \mathrm{mg} \cdot \mathrm{kg}^{-1}\right)$. The shoot dry weights of $P$. terminalis and $V$. minor were affected by the heavy metals in the substrate with the greatest degree by Cd. A $25 \mathrm{mg} \cdot \mathrm{kg}^{-1}$ of Cd caused a reduction of about $63 \%$ and $30 \%$ of shoot dry weights of $P$. terminalis, and $V$. minor, respectively, compared to controls $\left(\mathrm{Cd} 0 \mathrm{mg} \cdot \mathrm{kg}^{-1}\right)$. There was no reduction in $P$. terminalis, and $V$. minor grown under both $\mathrm{Pb} 250 \mathrm{mg} \cdot \mathrm{kg}^{-1}$ and $500 \mathrm{mg} \cdot \mathrm{kg}^{-1}$ treatments. Under the $\mathrm{Pb} 1,000 \mathrm{mg} \cdot \mathrm{kg}^{-1}$ treatment, a $3.7 \%$ of dry weight loss observed in P. terminalis compared to control $\left(\mathrm{Pb} 0 \mathrm{mg} \cdot \mathrm{kg}^{-1}\right)$; however, no reduction was found in $V$. minor. Zn-treated $V$. minor had no reduction of dry weight compared to controls $\left(\mathrm{Zn} 0 \mathrm{mg} \cdot \mathrm{kg}^{-1}\right)$, whereas in P. terminalis, about $11 \%, 26 \%$, and $52 \%$ reductions were observed under $\mathrm{Zn} 500,1,000$, and $2,000 \mathrm{mg} \cdot \mathrm{kg}^{-1}$ treatments, respectively. These results reveal that $V$. minor is more tolerant to $\mathrm{Pb}$ and $\mathrm{Zn}$ toxicity than is $P$. terminalis, and provide reference ranges for heavy metal concentrations in substrate that will be useful in further studies.

Keywords: accumulation; Pachysandra terminalis; polluted urban soil; heavy metal tolerance; Vinca minor
\end{abstract}

\section{Introduction}

Certain heavy metals in soil are essential to plants as trace elements, such as iron $(\mathrm{Fe})$, copper $(\mathrm{Cu})$, zinc $(\mathrm{Zn})$, manganese $(\mathrm{Mn})$, and nickel $(\mathrm{Ni})$; they are important constituents of many enzymes and proteins (Hagemeyer, 2004; Naz et al., 2015). Though they are necessary in small quantities, these elements become toxic to plants when they are present at higher concentrations in the soil (Kumar et al., 2013). Lead $(\mathrm{Pb})$ and cadmium $(\mathrm{Cd})$ are not essential for the function of plants (Vesna et al., 2012). Heavy metals inhibit growth and development of plants by disturbing many biochemical and physiological processes (Lai et al., 2012; Maksymiec, 2007). Plants develop a number of unique defense mechanisms and acclimation strategies; these enhance their tolerance to heavy metal stress (Xu et al., 2008).

Heavy metal contamination in soil occurs from both natural and anthropogenic sources in the local ecosystem (Gürcan et al., 2008). While natural occurrence is relatively rare, the number and intensity of anthropogenic sources, such as rubbish tips, 
smelter stacks, waste incineration fertilizers, vehicle emissions, agricultural waste, and sewage sludge are important determinants of environmental heavy metal concentrations (Koch and Rotard, 2001). Anthropogenic sources of increased heavy metal content in both terrestrial and aquatic systems are common in urban areas (Kumar et al., 2013).

Rapidly increasing population and unplanned urbanization are challenges to ecological balance (Gürcan et al., 2008). Anthropogenic soil pollution is usually not limited to a single pollutant. Several metals may be present at high concentrations in soil (Marchiol et al., 2004). Cd, Cr, and Ni have been found in contaminated urban soils (Lavado et al., 1998; Naz et al., 2015), as have $\mathrm{Cu}, \mathrm{Pb}$, and $\mathrm{Zn}$ (Kabala and Singh, 2001; Yoon et al., 2006). Therefore, it is necessary to identify plant species that are resistant to several different kinds of heavy metals, which are able to survive, grow, and reproduce by excluding or accumulating metals present at very high levels in the soil (Franiel and Babczyńska, 2011; Farrag et al., 2012). However, a limited amount of research has been dedicated to describing the behavior of plants capable of accumulating heavy metals in soils contaminated with a number of different metals. Heavy metal uptake is subject to antagonistic, additive, and synergetic effects that heavy metals exert on one another (Marchiol et al., 2004).

Many studies have investigated the tolerance of groundcover plants to contaminated soil, mostly concerning turfgrass species suitable for urban environmental remediation (Dushenkov et al., 1995; Li et al., 2000; Qu et al., 2003), but only a few have focused on groundcover plants grown in an shady urban spaces. Scented geranium (Pelargonium sp.) was found to be tolerant to heavy metals via accumulation of the metals (KrishnaRaj et al., 2000; Arshad et al., 2008). In particular, Pelargonium hortorum was more tolerant of heavy metals than were other Pelargonium species (Orroño et al., 2009). However, there are also little available data on the growth responses of shady groundcover plants to metal stress.

P. terminalis, known as Japanese spurge, is a member of the Buxaceae family; it is a frost-hardy evergreen plant widely used for groundcover in Europe and North America owing to its strong shade tolerance and effectiveness in controlling weeds (Lee et al., 2002; Zhu and Beck, 1991; Zhou et al., 2005). Pachysandra is an East Asian-North American disjunct genus with two species in eastern Asia, $P$. axillaris and $P$. terminalis, and one species in eastern North America, P. procumbens (Zhihua and Jianhua, 2009). This plant displays a high rate of biomass production, tolerates polluted environments, and is useful for soil phytoremediation purposes. It grows best at $24^{\circ} \mathrm{C}$ to $25^{\circ} \mathrm{C}$ and can survive in Zone 5 in the United States, where the minimum temperature can drop to $10^{\circ} \mathrm{C}$ to $-20^{\circ} \mathrm{C}$ (Zhou et al., 2005). The genus Vinca in the Apocynaceae family comprises seven known species worldwide. Lesser periwinkle (Vinca minor L.) is used as an ornamental plant because of its lilac-blue flowers, and is also used as a medicinal plant as an important alkaloid, vincamine, is found in its leaves (Frahanikia et al., 2011). It is a perennial sub-shrub that is indigenous to northern Spain, western France, and central and southern Europe as far as the Caucasus; it has been naturalized in many regions (Mahnaz et al., 2010).

The objects of this pilot study were to determine the heavy metal toxicity threshold, which is the highest permissible content in a substrate used in urban landscaping, and maximum possible accumulation of heavy metals in shoots of $P$. terminalis and $V$. minor grown on substrate containing $\mathrm{Cd}, \mathrm{Pb}$, or $\mathrm{Zn}$. 


\section{Material and methods}

\section{Plant and soil preparation}

One-year-old plants ( $P$. terminalis and $V$. minor) grown in $12 \mathrm{~cm}$-diameter pots filled with artificial substrates (coco peat:perlite $(\mathrm{v} / \mathrm{v})=50: 50)$ were purchased from a local nursery (San-nea Botanical Garden, Chenonan, Chungnam, Korea) on April 15, 2014. All plants used in the experiments were 10-15 cm in height, and had 20-25 fully grown leaves. The plants were placed in a controlled greenhouse with a shade net and allowed to acclimatize for one month prior to transplant. Three replications with ten plants were placed in a randomized complete block design in a greenhouse of KonKuk University, Chungju, located at latitude $35^{\circ} 49^{\prime} \mathrm{N}$ and longitude $127^{\circ} 08^{\prime} \mathrm{E}$. Ten $P$. terminalis and ten $V$. minor plants were transplanted into each of the plastic containers $(50 \mathrm{~cm}$ wide $\times 35$ long $\times 8.5 \mathrm{~cm}$ deep $)$ on May 17, 2014. The inside of each container was covered with a white plastic sheet to avoid heavy metal leakage. The substrate used for this study was a commercially produced ridging (Shinshin Floricultural materials, Co., Seoul, Korea) composed of $20 \%$ peat moss, $15 \%$ coco peat, $20 \%$ vermiculite, $10 \%$ pine bark, $0.5 \%$ peat, and $0.5 \%$ river sand with $\mathrm{pH}$ 6.5. Prior to transplant, each metal was thoroughly mixed with $1 \mathrm{~kg}$ of airdried substrate, and then the mixture was used to fill the containers. The $\mathrm{Cd}$ was added at the concentration of 25,50 , or $100 \mathrm{mg} \cdot \mathrm{kg}^{-1}$. The $\mathrm{Pb}$ was added at the concentration of 250,500 , and $1,000 \mathrm{mg} \mathrm{kg}^{-1}$. The $\mathrm{Zn}$ was added at the concentration of $500,1,000$, or $2,000 \mathrm{mg} \mathrm{kg}^{-1}$. For control treatment, no heavy metal was added to the substrate. The plants were watered at three day intervals (approximately 100 $200 \mathrm{~mL}$ per pot each time) during the experimental period (Fig. 1).

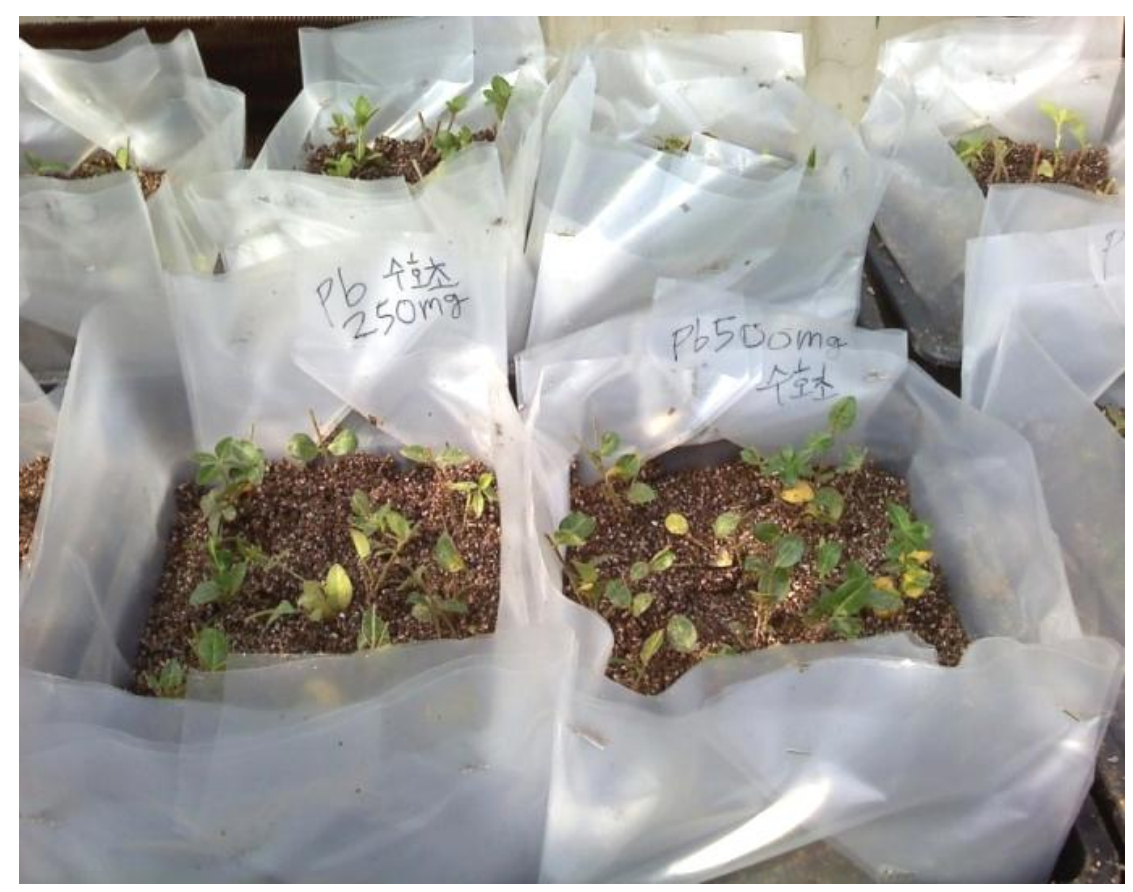

Figure 1. Images of plants grown on substrate containing heavy metals $(\mathrm{Cd}, \mathrm{Pb}$, and $\mathrm{Zn})$ in various concentrations. 


\section{Growth conditions}

Plants were grown in a greenhouse under natural light. During the experimental period, the air temperature and relative humidity were measured by a thermo recorder (SK-1260, SATO, Japan), and photosynthetically active radiation (PAR) was measured by a digital light meter (Extech 401025, EXTECH, USA). Air temperature ranged between $17^{\circ} \mathrm{C}$ and $35^{\circ} \mathrm{C}$, relative humidity between $30 \%$ and $70 \%$, and PAR between 0 and $300 \mu \mathrm{mol} \mathrm{m-}{ }^{2} \cdot \mathrm{s}^{-1}$.

\section{Measurements}

Growth parameters, including plant height, length and width of leaves, number of dead leaves, secondary shoots, number of living leaves, and survival rate of thirty plants per treatment were recorded during the active growth period. Plant height was measured as the distance between the stem base and the shoot apex. Leaf length and width were measured from the $3^{\text {rd }}$ fully expanded leaf above the stem base line. Leaves longer than $0.5 \mathrm{~cm}$ in length were counted as the number of leaves. Dead leaves and secondary shoots per plant were counted. Survival rates were calculated by comparing the number of plants in ideal and normal condition versus the number of plants in weakened and dry condition using the following formula: Survival rate $=$ (surviving plants/ total plants $) \times$ $100(\%)$. After 6 months of growth, the above-ground segments of the plants were harvested; they were washed with water and then rinsed with deionized distilled water to remove foreign objects; they were then oven dried at $60^{\circ} \mathrm{C}$ for $48 \mathrm{~h}$ and ground into powder using a grinder. $2.0 \mathrm{~g}$ of dried sample was placed into a $150 \mathrm{~mL}$ Erlenmeyer flask with $10 \mathrm{~mL}$ concentrated $\mathrm{HNO}_{3}$ for $24 \mathrm{~h}$, which point $20 \mathrm{~mL}$ of ternary solution $\left(\mathrm{HNO}_{3}: \mathrm{H}_{2} \mathrm{SO}_{4}: \mathrm{HClO}_{4}=10: 1: 4\right)$ was added. The sample was initially heated slowly on a $100-200^{\circ} \mathrm{C}$ hot plate until frothing ceased, and then further heated until the solution became clear and white fumes appeared. Digested plant samples were filtered through Whatman filter paper (No. 42) before metal analysis, and then heavy metal concentrations were determined with an atomic absorption spectrophotometer (ICP, Optima 5300DV, Perkin Elmer, USA). All samples were analyzed in three replicates. Heavy metal concentration was calculated as $C=P \times V \times K T S / m$ (Tian et al., 2013), where $C$ is the heavy metal concentration in the plant $\left(\mathrm{mg} \mathrm{kg}^{-1}\right), P$ is the sample concentration measured by ICP $\left(\mathrm{mg} \mathrm{L}^{-1}\right), V$ is the constant volume of the sample liquid $(50 \mathrm{~mL}), K T S$ is the divided multiples, and $m$ is the weight of the dried samples (g).

The soil thresholds for heavy metal toxicity and maximum possible accumulation were defined on the basis of a $10 \%$ reduction in shoot dry matter yield (Yang et al., 2002).

\section{Statistical analysis}

Statistical analyses were done with the SPS program (SPSS Inc., Chicago, IL, USA, Version 18.0), using Duncan's multiple range test (DMRT) to compare means at a significance level of 5\%. Single correlation analysis was performed and Pearson's correlation coefficients ( $r$ ) were reported in order to assess the relationship between heavy metal concentration and growth, as well as that between heavy metal concentration in the substrate and metal accumulation in plants. 


\section{Results}

\section{Plant growth in relation to heavy metals}

The growth and biomass of both $P$. terminalis and $V$. minor were significantly affected by all of the tested heavy metals; Cd affected both to the greatest degree. Cd 25 $\mathrm{mg} \cdot \mathrm{kg}^{-1}$ treatment decreased the number of lateral shoots and the numbr of total leaves of $P$. terminalis by about $43 \%$ and $7 \%$, respectively (Table 1 ). $\mathrm{Cd} 25 \mathrm{mg} \cdot \mathrm{kg}^{-1}$ treatment decreased the total leaf number of $V$. minor decreased by $33 \%$. There was no significant difference in the lateral shoot number of $V$. minor with either Cd 25 or $50 \mathrm{mg} \cdot \mathrm{kg}^{-1}$ treatments, however, the lateral shoot number decreased by $53 \%$ with $\mathrm{Cd} 100 \mathrm{mg} \cdot \mathrm{kg}^{-1}$ treatment. A $10 \%$ reduction in survival rate of $P$. terminalis was caused by both $\mathrm{Cd} 50$ and $100 \mathrm{mg} \cdot \mathrm{kg}^{-1}$ treatments, while the survival rate of $V$. minor decreased only with $\mathrm{Cd}$ $100 \mathrm{mg} \cdot \mathrm{kg}^{-1}$ treatment by $10 \%$.

Table 1. Growth and survival rate of Pachysandra terminalis and Vinca minor as affected by the substrate cadmium (Cd) concentrations during actively growing period (July, 2014).

\begin{tabular}{|c|c|c|c|c|c|c|c|c|}
\hline Species & $\begin{array}{c}\text { Added } \\
\text { Cd } \\
\left(\mathrm{mg} \mathrm{kg}^{-1}\right)\end{array}$ & $\begin{array}{c}\text { Plant } \\
\text { height } \\
(\mathrm{cm})\end{array}$ & $\begin{array}{c}\text { Leaf } \\
\text { length } \\
(\mathrm{cm})\end{array}$ & $\begin{array}{c}\text { Leaf } \\
\text { width } \\
(\mathrm{cm})\end{array}$ & $\begin{array}{c}\text { Secondary } \\
\text { shoots } \\
\left(\text { no. } \text { plant }^{-1}\right)\end{array}$ & $\begin{array}{c}\text { Total } \\
\text { leaves } \\
\left(\text { no. plant }{ }^{-1}\right)\end{array}$ & $\begin{array}{c}\text { Dead } \\
\text { leaves } \\
\text { (no. } \text { plant }^{-1} \text { ) }\end{array}$ & $\begin{array}{c}\text { Survival } \\
\text { rate }^{\mathrm{y}} \\
(\%)\end{array}$ \\
\hline \multirow{4}{*}{$\begin{array}{c}P . \\
\text { termi- } \\
\text { nalis }\end{array}$} & Control & $13.3 b^{\mathrm{z}}$ & $4.00 \mathrm{a}$ & $2.65 a$ & $7.50 \mathrm{a}$ & $28.0 \mathrm{a}$ & $0.25 \mathrm{~b}$ & 100 \\
\hline & 25 & $12.3 \mathrm{ab}$ & $3.50 \mathrm{a}$ & $2.07 \mathrm{ab}$ & $4.25 \mathrm{~b}$ & $26.0 \mathrm{~b}$ & $0.50 \mathrm{ab}$ & 100 \\
\hline & 50 & $12.3 \mathrm{ab}$ & $3.40 \mathrm{a}$ & $2.00 \mathrm{~b}$ & $3.25 \mathrm{~b}$ & $25.5 b$ & $0.65 \mathrm{ab}$ & 90 \\
\hline & 100 & $10.3 b$ & $3.38 \mathrm{a}$ & $1.80 \mathrm{~b}$ & $3.00 \mathrm{~b}$ & $25.0 \mathrm{~b}$ & $1.80 \mathrm{a}$ & 90 \\
\hline \multirow{4}{*}{$\begin{array}{c}V . \\
\text { minor }\end{array}$} & Control & $30.7 \mathrm{a}$ & $2.77 \mathrm{a}$ & $1.52 \mathrm{a}$ & $3.75 \mathrm{a}$ & $49.8 \mathrm{a}$ & $0.50 \mathrm{~b}$ & 100 \\
\hline & 25 & $16.6 \mathrm{~b}$ & $2.30 \mathrm{ab}$ & $1.47 \mathrm{a}$ & $3.75 \mathrm{a}$ & $33.3 b$ & $1.75 \mathrm{ab}$ & 100 \\
\hline & 50 & $11.5 b c$ & $1.85 b c$ & $1.13 b$ & $3.25 \mathrm{a}$ & $20.0 \mathrm{c}$ & $3.25 \mathrm{a}$ & 100 \\
\hline & 100 & $6.75 \mathrm{c}$ & $1.65 \mathrm{c}$ & $1.12 b$ & $1.75 \mathrm{~b}$ & $7.00 \mathrm{~d}$ & $3.75 \mathrm{a}$ & 90 \\
\hline
\end{tabular}

${ }^{\mathrm{z}}$ Different letters in the same column indicate significant difference according to Duncan's multiple range test at $P \leq$ $0.05(\mathrm{n}=10)$.

${ }^{\mathrm{y}}$ Survival rate $(\%)=($ surviving plants/total plants $) \times 100$.

Unlike $\mathrm{Cd}, \mathrm{Pb}$ had no significant effect on the lateral shoot number of $V$. minor, and only affected $P$. terminalis at a concentration of $1,000 \mathrm{mg} \cdot \mathrm{kg}^{-1}$, which resulted in a $59 \%$ reduction (Table 2). $P$. terminalis total leaf number was not affected by $\mathrm{Pb}$ treatment, while the total leaf number of $V$. minor decreased by $30 \%$ and $48 \%$ at $\mathrm{Pb} 500$ and $1,000 \mathrm{mg} \cdot \mathrm{kg}^{-1}$, respectively.

There was a significant difference in plant growth responses between the two species following $\mathrm{Zn}$ treatment. $V$. minor was more tolerant to $\mathrm{Zn}$ than was $P$. terminalis. At $\mathrm{Zn}$ $500 \mathrm{mg} \cdot \mathrm{kg}^{-1}$, the secondary shoot number of P. terminalis decreased by $53 \%$ (Table 3 ), whereas there was no significant difference in the secondary shoot number of $V$. minor under $\mathrm{Zn} 500$ and $1,000 \mathrm{mg} \cdot \mathrm{kg}^{-1}$ treatments, and there was a $27 \%$ decrease at $\mathrm{Zn} \mathrm{2,000}$ $\mathrm{mg} \cdot \mathrm{kg}^{-1}$. When treated with $\mathrm{Zn} 500 \mathrm{mg} \cdot \mathrm{kg}^{-1}$, the total leaf number of $V$. minor actually increased by $54 \%$ compared to control plants. With both $\mathrm{Zn} 1,000$ and $2,000 \mathrm{mg} \cdot \mathrm{kg}^{-1}$ treatments, there were no significant differences in total leaf number, dead leaf number, or survival rate of $V$. minor. 
Table 2. Growth and survival rate of Pachysandra terminalis and Vinca minor as affected by the substrate lead $(\mathrm{Pb})$ concentrations during actively growing period (July, 2014).

\begin{tabular}{|c|c|c|c|c|c|c|c|c|}
\hline Species & $\begin{array}{c}\text { Added } \\
\mathrm{Pb} \\
\left(\mathrm{mg} \mathrm{kg}^{-1}\right)\end{array}$ & $\begin{array}{c}\text { Plant } \\
\text { height } \\
(\mathrm{cm})\end{array}$ & $\begin{array}{l}\text { Leaf } \\
\text { length } \\
(\mathrm{cm})\end{array}$ & $\begin{array}{c}\text { Leaf } \\
\text { width } \\
(\mathrm{cm})\end{array}$ & $\begin{array}{c}\text { Secondary } \\
\text { shoots } \\
\left(\text { no. } \text { plant }^{-1}\right)\end{array}$ & $\begin{array}{c}\text { Total } \\
\text { leaves } \\
\left(\text { no. } \text { plant }^{-1}\right)\end{array}$ & $\begin{array}{c}\text { Dead } \\
\text { leaves } \\
\left(\text { no. } \text { plant }^{-1}\right)\end{array}$ & $\begin{array}{c}\text { Survival } \\
\text { rate }^{\mathrm{y}} \\
(\%)\end{array}$ \\
\hline \multirow{4}{*}{$\begin{array}{c}P . \\
\text { termi- } \\
\text { nalis }\end{array}$} & Control & $13.3 \mathrm{a}^{\mathrm{z}}$ & $3.50 \mathrm{a}$ & $2.65 \mathrm{a}$ & $4.25 \mathrm{~b}$ & $25.5 \mathrm{c}$ & $0.75 \mathrm{a}$ & 100 \\
\hline & 250 & $14.5 \mathrm{a}$ & $4.00 \mathrm{a}$ & $2.20 \mathrm{ab}$ & $7.50 \mathrm{a}$ & $62.0 \mathrm{a}$ & $0.75 \mathrm{a}$ & 100 \\
\hline & 500 & $12.5 \mathrm{a}$ & $3.75 \mathrm{a}$ & $2.00 \mathrm{~b}$ & $5.00 \mathrm{~b}$ & $40.0 \mathrm{~b}$ & $1.00 \mathrm{a}$ & 100 \\
\hline & 1,000 & $9.75 \mathrm{~b}$ & $3.25 \mathrm{ab}$ & $1.75 \mathrm{~b}$ & $1.75 \mathrm{c}$ & $33.0 \mathrm{~b}$ & $1.25 \mathrm{a}$ & 100 \\
\hline \multirow{4}{*}{$\begin{array}{c}V . \\
\text { minor }\end{array}$} & Control & $30.7 \mathrm{ab}$ & $2.77 \mathrm{a}$ & $1.52 \mathrm{a}$ & $3.75 \mathrm{a}$ & $49.8 \mathrm{ab}$ & $0.50 \mathrm{~b}$ & 100 \\
\hline & 250 & $39.5 \mathrm{a}$ & $2.67 \mathrm{a}$ & $1.30 \mathrm{ab}$ & $4.25 \mathrm{a}$ & $72.0 \mathrm{a}$ & $1.50 \mathrm{a}$ & 100 \\
\hline & 500 & $27.9 \mathrm{~b}$ & $2.42 \mathrm{a}$ & $1.20 \mathrm{ab}$ & $3.50 \mathrm{a}$ & $35.0 \mathrm{bc}$ & $3.25 \mathrm{a}$ & 100 \\
\hline & 1,000 & $12.8 \mathrm{c}$ & $2.17 \mathrm{a}$ & $1.05 \mathrm{~b}$ & $2.75 \mathrm{a}$ & $25.8 \mathrm{c}$ & $3.25 \mathrm{a}$ & 100 \\
\hline
\end{tabular}

${ }^{\mathrm{z}}$ Different letters in the same column indicate significant difference according to Duncan's multiple range test at $P \leq$ $0.05(\mathrm{n}=10)$.

${ }^{\mathrm{y}}$ Survival rate $(\%)=($ surviving plants/total plants $) \times 100$.

Table 3. Growth and survival rate of Pachysandra terminalis and Vinca minor as affected by the substrate zinc (Zn) concentrations during actively growing period (July, 2014).

\begin{tabular}{|c|c|c|c|c|c|c|c|c|}
\hline Species & $\begin{array}{c}\text { Added } \\
\mathrm{Zn} \\
\left(\mathrm{mg} \mathrm{kg}^{-1}\right)\end{array}$ & $\begin{array}{c}\text { Plant } \\
\text { height } \\
(\mathrm{cm})\end{array}$ & $\begin{array}{c}\text { Leaf } \\
\text { length } \\
(\mathrm{cm})\end{array}$ & $\begin{array}{l}\text { Leaf } \\
\text { width } \\
(\mathrm{cm})\end{array}$ & $\begin{array}{l}\text { Secondary } \\
\text { shoots } \\
\left(\text { no. } \text { plant }^{-1}\right)\end{array}$ & $\begin{array}{c}\text { Total } \\
\text { leaves } \\
\text { (no. } \text { plant }^{-1} \text { ) }\end{array}$ & $\begin{array}{c}\text { Dead } \\
\text { leaves } \\
\left.\text { (no. plant }{ }^{-1}\right)\end{array}$ & $\begin{array}{c}\text { Survival } \\
\text { rate }^{\mathrm{y}} \\
(\%)\end{array}$ \\
\hline \multirow{4}{*}{$\begin{array}{c}P . \\
\text { termi- } \\
\text { nalis }\end{array}$} & Control & $13.3 \mathrm{a}^{\mathrm{Z}}$ & $3.50 \mathrm{a}$ & $2.65 a$ & $7.50 \mathrm{a}$ & $25.5 a$ & $0.75 a$ & 100 \\
\hline & 500 & $14.3 \mathrm{a}$ & $3.32 \mathrm{a}$ & $2.07 \mathrm{ab}$ & $3.50 \mathrm{~b}$ & $31.8 \mathrm{a}$ & $0.50 \mathrm{a}$ & 100 \\
\hline & 1,000 & $11.8 \mathrm{a}$ & $3.20 \mathrm{a}$ & $2.07 \mathrm{ab}$ & $2.75 b$ & $31.3 \mathrm{a}$ & $0.50 \mathrm{a}$ & 90 \\
\hline & 2,000 & $11.6 \mathrm{a}$ & $2.87 \mathrm{a}$ & $1.93 b$ & $2.50 \mathrm{~b}$ & $28.3 \mathrm{a}$ & $0.25 \mathrm{a}$ & 80 \\
\hline \multirow{4}{*}{$\begin{array}{c}V . \\
\text { minor }\end{array}$} & Control & $30.7 b$ & $2.77 \mathrm{a}$ & $1.52 \mathrm{a}$ & $3.75 \mathrm{a}$ & $49.8 b$ & $0.50 \mathrm{a}$ & 100 \\
\hline & 500 & $42.5 a$ & $2.67 \mathrm{a}$ & $1.55 \mathrm{a}$ & $4.00 \mathrm{a}$ & $76.8 \mathrm{a}$ & $0.50 \mathrm{a}$ & 100 \\
\hline & 1,000 & $39.3 \mathrm{ab}$ & $2.62 \mathrm{a}$ & $1.52 \mathrm{a}$ & $3.00 \mathrm{a}$ & $56.8 \mathrm{ab}$ & $0.50 \mathrm{a}$ & 100 \\
\hline & 2,000 & $29.3 b$ & $2.37 \mathrm{a}$ & $1.50 \mathrm{ab}$ & $2.75 \mathrm{ab}$ & $47.3 b$ & $0.50 \mathrm{a}$ & 100 \\
\hline
\end{tabular}

${ }^{\mathrm{z}}$ Different letters in the same column indicate significant difference according to Duncan's multiple range test at $P \leq$ $0.05(\mathrm{n}=10)$.

${ }^{\mathrm{y}}$ Survival rate $(\%)=($ surviving plants/total plants $) \times 100$.

\section{Correlation coefficient analysis}

The Pearson correlation coefficients between the heavy metal concentrations in substrate and the growth of $P$. terminalis showed that, of the three heavy metals tested, substrate $\mathrm{Cd}$ concentration was the most positively correlated with shoot $\mathrm{Cd}$ concentration ( $\mathrm{r}=0.98, P<0.01)$; substrate $\mathrm{Pb}$ and $\mathrm{Zn}$ concentrations were also positively correlated with shoot $\mathrm{Pb}(\mathrm{r}=0.92, P<0.01)$ and $\mathrm{Zn}$ concentrations $(\mathrm{r}=0.95, P$ $<0.01$ ) (Table 4). Substrate Cd concentration was negatively correlated with leaf width 
$(\mathrm{r}=0.49, P<0.01)$, lateral shoot number $(\mathrm{r}=0.47, P<0.01)$, and total leaf number $(\mathrm{r}=0.48, P<0.01)$, while substrate $\mathrm{Pb}$ concentration showed a significant negative correlation only with lateral shoot number $(\mathrm{r}=0.38, P<0.05)$. Substrate $\mathrm{Zn}$ concentration was negatively correlated with leaf length $(\mathrm{r}=0.35, P<0.05)$, leaf width $(\mathrm{r}=0.39, P<0.05)$, and lateral shoot number $(\mathrm{r}=0.56, P<0.01)$.

Table 4. The Pearson correlation coefficients between heavy metal concentrations and growth characteristics of Pachysandra terminalis.

\begin{tabular}{cccccccc}
\hline Metal & $\begin{array}{c}\text { Plant } \\
\text { height }\end{array}$ & $\begin{array}{c}\text { Leaf } \\
\text { length }\end{array}$ & $\begin{array}{c}\text { Leaf } \\
\text { width }\end{array}$ & $\begin{array}{c}\text { Secondary } \\
\text { shoot no. }\end{array}$ & $\begin{array}{c}\text { Total } \\
\text { leaf no. }\end{array}$ & $\begin{array}{c}\text { Dead } \\
\text { leaf no. }\end{array}$ & $\begin{array}{c}\text { Shoot metal } \\
\text { concentration }\end{array}$ \\
\hline $\mathrm{Cd}$ & $-0.338^{*}$ & $-0.385^{*}$ & $-0.493^{* *}$ & $-0.473^{* *}$ & $-0.482^{* *}$ & -0.231 & $0.979^{* *}$ \\
$\mathrm{~Pb}$ & -0.025 & -0.015 & -0.273 & $-0.376^{*}$ & -0.122 & -0.224 & $0.917^{* *}$ \\
$\mathrm{Zn}$ & -0.194 & $-0.345^{*}$ & $-0.393^{*}$ & $-0.561^{* *}$ & -0.221 & 0.039 & $0.949^{* *}$ \\
\hline
\end{tabular}

,*** Significant at $P<0.05$ or 0.01 , respectively $(\mathrm{n}=10)$.

\section{Heavy metal accumulation in shoots in relation to substrate heavy metal concentrations}

The Cd $25 \mathrm{mg} \cdot \mathrm{kg}^{-1}$ caused a reduction in shoot dry weight of about $63 \%$ and $30 \%$ in $P$. terminalis and $V$. minor, respectively, compared with control plants (Table 5). The $\mathrm{Cd} 100 \mathrm{mg} \cdot \mathrm{kg}^{-1}$ treated $P$. terminalis and $V$. minor had $74 \%$ and $60 \%$ lower shoot dry weights than did their controls, respectively. Both $\mathrm{Pb} 250$ and $500 \mathrm{mg} \cdot \mathrm{kg}^{-1}$ treatments caused no reduction in shoot biomass of either P. terminalis or $V$. minor. The $\mathrm{Pb} 1,000$ $\mathrm{mg} \cdot \mathrm{kg}^{-1}$ treatment caused a reduction in $P$. terminalis dry weight of about $3.7 \%$, whereas no reduction was observed in $V$. minor dry weight. Zn-treated $V$. minor had no reduction in dry weight, whereas for $P$. terminalis, about $11 \%, 26 \%$, and $52 \%$ reductions were recorded under $\mathrm{Zn} \mathrm{500,} \mathrm{1,000} \mathrm{and} \mathrm{2,000} \mathrm{mg} \cdot \mathrm{kg}^{-1}$ treatments, respectively.

The accumulation of $\mathrm{Cd}$ in the shoot tissues of both $P$. terminalis and $V$. minor linearly increased when Cd concentration in the substrate was increased to $100 \mathrm{mg} \cdot \mathrm{kg}^{-1}$. Accumulation of $\mathrm{Cd}$ in the shoots was 3- to 4-fold higher in $V$. minor than in $P$. terminalis. With Cd $25 \mathrm{mg} \cdot \mathrm{kg}^{-1}$ treatment, the shoot Cd concentrations were $2.1 \mathrm{mg} \mathrm{kg}^{-1}$ for $P$. terminalis and $5.8 \mathrm{mg} \mathrm{kg}{ }^{-1}$ for $V$. minor (Table 5). With $\mathrm{Cd} 100 \mathrm{mg} \cdot \mathrm{kg}^{-1}$ treatment, the shoot Cd concentrations were 4.5 and $11.5 \mathrm{mg} \cdot \mathrm{kg}^{-1}$ in $P$. terminalis and $V$. minor, respectively. The shoot $\mathrm{Pb}$ concentrations for both species increased when the concentration of $\mathrm{Pb}$ in the substrate increased. The shoot $\mathrm{Pb}$ concentration of $P$. terminalis was $1.2 \mathrm{mg} \cdot \mathrm{kg}^{-1}$ with $\mathrm{Pb} 250 \mathrm{mg} \cdot \mathrm{kg}^{-1}$ treatment, almost 2-fold higher than that of control plants $\left(0.71 \mathrm{mg} \cdot \mathrm{kg}^{-1}\right)$, however, very little change was seen in the shoot $\mathrm{Pb}$ concentration between $\mathrm{Pb} 250$ and $1,000 \mathrm{mg} \cdot \mathrm{kg}^{-1}$ treatments, with $1.43 \mathrm{mg} \cdot \mathrm{kg}^{-1}$ being the maximum value at a substrate $\mathrm{Pb}$ concentration of $1,000 \mathrm{mg} \cdot \mathrm{kg}^{-1}$. The shoot $\mathrm{Pb}$ concentration of $V$. minor increased 1.6-fold, from 1.25 to $1.96 \mathrm{mg} \cdot \mathrm{kg}^{-1}$, when $\mathrm{Pb}$ concentration in the substrate was increased from 500 to $1,000 \mathrm{mg} \cdot \mathrm{kg}^{-1}$. The shoot $\mathrm{Zn}$ concentration of both species increased with increasing external $\mathrm{Zn}$ levels. The shoot $\mathrm{Zn}$ concentrations of $P$. terminalis were $0.32,5.21,15.3$, and $38.1 \mathrm{mg} \cdot \mathrm{kg}^{-1}$, and those of $V$. minor were $2.12,6.54,11.8$, and $34.2 \mathrm{mg} \cdot \mathrm{kg}^{-1}$, when grown in substrate with $\mathrm{Zn}$ added at concentrations, $0,500,1,000$, and $2,000 \mathrm{mg} \cdot \mathrm{kg}^{-1}$, respectively. 
Table 5. Shoot dry weight, shoot metal concentration and reduction of shoot dry weight relative to control plant of Pachysandra terminalis and Vinca minor as influenced by heavy metals added to substrate at different concentrations.

\begin{tabular}{|c|c|c|c|c|}
\hline Species & $\begin{array}{l}\text { Heavy metal } \\
\text { treatments } \\
\left(\mathrm{mg} \mathrm{kg}^{-1}\right)\end{array}$ & $\begin{array}{c}\text { Shoot dry weight } \\
\left(\text { g plant }^{-1}\right)\end{array}$ & $\begin{array}{c}\text { Shoot metal } \\
\text { concentration } \\
\left(\mathrm{mg} \mathrm{kg}^{-1}\right)\end{array}$ & $\begin{array}{l}\text { Reduction of shoot } \\
\text { dry weight relative to } \\
\text { control plant }(\%)\end{array}$ \\
\hline \multirow{12}{*}{$\begin{array}{c}P . \\
\text { terminalis }\end{array}$} & $\mathrm{Cd} 0$ & $2.7^{\mathrm{az}}$ & $0.04^{\mathrm{d}}$ & - \\
\hline & $\mathrm{Cd} 25$ & $1.0^{\mathrm{b}}$ & $2.15^{\mathrm{c}}$ & 63 \\
\hline & $\mathrm{Cd} 50$ & $0.9^{\mathrm{b}}$ & $2.69^{\mathrm{b}}$ & 67 \\
\hline & $\mathrm{Cd} 100$ & $0.7^{\mathrm{c}}$ & $4.51^{\mathrm{a}}$ & 74 \\
\hline & $\mathrm{Pb} 0$ & $2.7^{\mathrm{ab}}$ & $0.71^{\mathrm{c}}$ & - \\
\hline & $\mathrm{Pb} 250$ & $2.9^{\mathrm{a}}$ & $1.20^{\mathrm{b}}$ & 0 \\
\hline & $\mathrm{Pb} 500$ & $2.8^{\mathrm{ab}}$ & $1.33^{\mathrm{a}}$ & 0 \\
\hline & $\mathrm{Pb} 1,000$ & $2.6^{\mathrm{b}}$ & $1.43^{\mathrm{a}}$ & 3.7 \\
\hline & $\mathrm{Zn} 0$ & $2.7^{\mathrm{a}}$ & $0.32^{\mathrm{d}}$ & - \\
\hline & Zn500 & $2.4^{\mathrm{b}}$ & $5.21^{\mathrm{c}}$ & 11 \\
\hline & $\mathrm{Zn} 1,000$ & $2.0^{\mathrm{c}}$ & $15.3^{\mathrm{b}}$ & 26 \\
\hline & $\mathrm{Zn} 2,000$ & $1.3^{\mathrm{d}}$ & $38.1^{\mathrm{a}}$ & 52 \\
\hline \multirow{12}{*}{$V$. minor } & $\mathrm{Cd} 0$ & $1.0^{\mathrm{a}}$ & $0.94^{\mathrm{d}}$ & - \\
\hline & $\mathrm{Cd} 25$ & $1.0^{\mathrm{a}}$ & $5.78^{\mathrm{c}}$ & 30 \\
\hline & $\mathrm{Cd} 50$ & $0.8^{\mathrm{b}}$ & $8.38^{\mathrm{b}}$ & 50 \\
\hline & $\mathrm{Cd} 100$ & $0.7^{\mathrm{b}}$ & $11.5^{\mathrm{a}}$ & 30 \\
\hline & $\mathrm{Pb} 0$ & $1.0^{\mathrm{b}}$ & $0.43^{\mathrm{d}}$ & - \\
\hline & $\mathrm{Pb} 250$ & $1.3^{\mathrm{a}}$ & $1.19^{\mathrm{c}}$ & 0 \\
\hline & $\mathrm{Pb} 500$ & $1.2^{\mathrm{a}}$ & $1.25^{\mathrm{b}}$ & 0 \\
\hline & $\mathrm{Pb} 1,000$ & $1.0^{\mathrm{b}}$ & $1.96^{\mathrm{a}}$ & 0 \\
\hline & $\mathrm{Zn} 0$ & $1.0^{\mathrm{c}}$ & $2.12^{\mathrm{d}}$ & - \\
\hline & Zn500 & $1.6^{\mathrm{a}}$ & $6.54^{\mathrm{c}}$ & 0 \\
\hline & $\mathrm{Zn} 1,000$ & $1.3^{\mathrm{b}}$ & $11.8^{\mathrm{b}}$ & 0 \\
\hline & $\mathrm{Zn} 2,000$ & $1.2^{\mathrm{b}}$ & $34.2^{\mathrm{a}}$ & 0 \\
\hline
\end{tabular}

${ }^{\mathrm{z}}$ Different letters in the same column indicate significant difference according to Duncan's multiple range test at $P \leq$ 0.05 .

\section{Discussion}

The results from this pilot study indicate that excessive levels of heavy metals added to substrate significantly affect the growth and development of two groundcover plants commonly used in urban landscapes. The $\mathrm{Cd}$ caused the greatest degree of growth inhibition in both species (Tables 1, 2, and 3). Some previous studies support this result. The $\mathrm{Cd}$ is more toxic than $\mathrm{Cu}, \mathrm{Pb}$, and particularly $\mathrm{Zn}$ (Kahle, 1993) because of its high solubility in water and its phototoxic effects (Wang et al., 2008). The Cd damages membranes and disrupts membrane electron transport, interacts with nucleic acids, and reduces mitotic activity (Zhang et al., 2009). Also, the $\mathrm{Cd}$ is the heavy metal most readily absorbed by plants. The Cd toxicity causes leaf rolls, chlorosis, and reduced plant growth (Zhang et al., 2009).

The Pearson correlation coefficients between the heavy metal levels and the growth of $P$. terminalis shows that shoot numbers and metal accumulation in the shoots are good indicators of toxicity for all three tested metals (Table 4). This study aimed to determine the heavy metal toxicity threshold in the substrate that caused a reduction in shoot dry matter of at most 10\%; however, the substrate threshold and maximum 
possible accumulation in shoots was obtained only for $\mathrm{Zn}$ toxicity in $P$. terminalis (Table 5). The substrate $\mathrm{Zn}$ threshold was $500 \mathrm{mg} \cdot \mathrm{kg}^{-1}$ and the maximum possible accumulation of $\mathrm{Zn}$ was $5 \mathrm{mg} \cdot \mathrm{kg}^{-1}$ (Table 5). The lowest $\mathrm{Cd}$ concentration applied to the substrate in this study, Cd $25 \mathrm{mg} \cdot \mathrm{kg}^{-1}$ treatment, caused shoot Cd accumulation of about $2.1 \mathrm{mg} \cdot \mathrm{kg}^{-1}$ for $P$. terminalis and $5.8 \mathrm{mg} \cdot \mathrm{kg}^{-1}$ for $V$. minor, which exceed acceptable tissue levels of Cd by between 0.02 and $0.5 \mathrm{mg} \cdot \mathrm{kg}^{-1}$ (Ward, 1995).

In contrast, the highest $\mathrm{Pb}$ concentration in the substrate, $\mathrm{Pb} 1,000 \mathrm{mg} \cdot \mathrm{kg}^{-1}$, caused only a $3.7 \%$ reduction in biomass of $P$. terminalis, and no significant biomass reduction in $V$. minor was observed. The shoot concentrations of $\mathrm{Pb}$ in $V$. minor and $P$. terminalis were 1.4 and $2.0 \mathrm{mg} \cdot \mathrm{kg}^{-1}$, respectively (Table 5), which are in the range of adequate tissue levels of $\mathrm{Pb}$ (between 0.1 and $10 \mathrm{mg} \cdot \mathrm{kg}^{-1}$ ) (Bohn et al., 1989). Although plants are mainly sensitive to the presence of $\mathrm{Pb}$ (Pahlsson, 1989) because of its inhibitory effects on photosynthesis (Qureshi et al., 2007), a soil Pb concentration of $1,000 \mathrm{mg} \mathrm{kg}^{-}$ ${ }^{1}$ did not prove to be the absolute threshold value for hyperaccumulation (Baker, 2000). $\mathrm{Pb}$ concentration over $30 \mu \mathrm{g} \mathrm{g}^{-1}$ dry biomass is toxic to most plant species (Qureshi et al., 2007). These previous results indicate that the two species in the present study can be considered tolerant to $\mathrm{Pb}$.

The results of shoot biomass and shoot $\mathrm{Zn}$ accumulation measurements suggest that $V$. minor is more tolerant than is $P$. terminalis to $\mathrm{Zn}$ (Table 5). The maximum possible accumulation of $\mathrm{Zn}, 5 \mathrm{mg} \cdot \mathrm{kg}^{-1}$, did not exceed the toxicity value, about $100 \mathrm{mg} \cdot \mathrm{kg}^{-1}$ (Anjum et al., 2015), but was in the range of adequate tissue $\mathrm{Zn}$ levels, variously reported as 15 to $20 \mathrm{mg} \cdot \mathrm{kg}^{-1}$ dry weight (Marschner, 1995), and 10 to $100 \mathrm{mg} \cdot \mathrm{kg}^{-1} \mathrm{dry}$ weight (Frisberg et al., 1986). Although some crops show toxicity symptoms at $\mathrm{Zn}$ levels less than $100 \mathrm{mg} \cdot \mathrm{kg}^{-1}$ dry weight (Chaney, 1997), the concentration of $\mathrm{Zn}$ that is toxic to most crops is between 100 and $300 \mu \mathrm{g} \cdot \mathrm{g}^{-1}$ (Marschner, 1995). In the present study, the Zn level added to the substrate was much higher than is normal in soils; it comprised a total fraction of 70 to $400 \mathrm{mg} \cdot \mathrm{kg}^{-1}$ of the soil (Anjum et al., 2015), indicating that $V$. minor is as a $\mathrm{Zn}$ tolerant plant, although it is not a hyperaccumulator. These results provide reference ranges for the heavy metal concentrations in substrate for further studies.

According to a previous report, hydroponics is the most frequent method used to determine the effect of heavy metals as it allows for direct exposure of plants to toxic metals (Zeliha et al., 2011). A recent study, in which 18 populations were cultivated in 18 different growth conditions, such as a soil mine tailing, soils supplemented with Zn, $\mathrm{Cd}$, and $\mathrm{Ni}$ salts, and a hydroponic solution with two Zn concentrations, showed a large heterogeneity of responses among populations depending on the substrate used, although culture soils are closer to the conditions in fields than are hydroponics (Escarré et al., 2013). This report also suggests that it is necessary to conduct toxicity testing on different plant species using various substrates.

Acknowledgement. This paper was supported by Konkuk University in 2013.

\section{REFERENCE}

[1] Anjum, N.A., Singh, H.P., Khan, M.I.R., Masood, A., Per, T.S., Negi, A., Batish, D.R., Khan, N.A., Duarte, A.C., Pereir,a E., Ahmad, I. (2015): Too much is bad-an appraisal of 
phytotoxicity of elevated plant-beneficial heavy metal ions. - Environ. Sci. Pollut. Res. 22: 3361-3382.

[2] Arshad, M., Silvestre, J., Pinelli, E., Kallerhoff, J., Kaemmerer, M., Tarigo, A., Shahid, M., Guiresse, M., Pradere, P., Dumat, C. (2008): A field study of lead phytoextraction by various scented Pelargonium cultivars. - Chemosphere 71: 2187-2192.

[3] Baker, A.J.M., McGrath, S.P., Reeves, R.D., Smith, J.A.C. (2000): Metal hyperaccumulator plants: A review of ecology and physiology of a biological resource for phytoremediation of metal polluted soils, p 129-158. - In: Terry, N. (ed.) Phytoremediation of contaminated soil and water. Lewis Publisher, Boca Ratton, FL, USA.

[4] Bohn, H.L., McNeal, B.L., O'Connor, G.A. (1989): Soil chemistry, 2nd ed. - John Wiley $\&$ Sons, New York. USA.

[5] Chaney, R.L., Mailik, M., Li, Y.M., Brown, S.L., Brewer, E.P., Angle, J.S., Baker, A.J. (1997): Phytoremediation of soil metals. - Curr. Opin. Biotechnol. 8: 279-284.

[6] Dushenkov, V., Nanda Kumar, P.B.A., Motto, H., Raskin, I. (1995): Rhizofiltration: The use of plants to remove heavy metals from aqueous streams. - Environ. Sci. Technol. 29: 1239-1245.

[7] Escarré, J., Lefébvre, C., Frérot, H., Mahieu, S., Noret, N. (2013): Metal concentration and metal mass of metallicolous, non metallicolus and serpentine Noccaea caerulescens populations, cultivated in different growth media. - Plant Soil 370: 197-221.

[8] Farrag, K., Senesi, N., Nigro, F., Petrozza, A., Palma, A., Shaarawi, S., Brunetti, G. (2012): Growth responses of crop and weed species to heavy metals in pot and field experiments. - Environ. Sci. Pollut. Res. 19: 3636-3644.

[9] Franiel, I. Babczyńska, A. (2011): The growth and reproductive effort of Betula pendula Roth in a heavy-metals polluted area. - Polish J. Environ. Stud. 20: 1097-1101.

[10] Farahanikia, B., Akbarzadeh, T., Jahangirzadeh, A., Yassa, N., Ardekani, M., Mirnezami, T., Hadjiakhoondi, A., Khanavi, M. (2011) Phytochemical investigation of Vinca minor cultivated in Iran. - Journal of Pharmaceutical Research 10(4): 777-785.

[11] Frisberg, L., Nordberg, G.F., Kessler, E., Vouk, V.B. (1986): Handbook of the toxicology of metals. Volume I and II. - Elsevier Science Publisher, Amsterdam, the Netherlands.

[12] Gürcan, G., Arslan, H., Celik, C., Guer, S., Kendall, M. (2008): Heavy metal content of plant species along Nilufer stream in industrialized Bursa City, Turkey. - Water Air Soil Pollut. 195: 275-284.

[13] Hagemeyer, J. (2004): Ecophysiology of plant growth under heavy metal stress, p 201222. - In: Prasad, M.N.V. (ed.) Heavy metal stress in plants: From molecules to ecosystems, Springer, Berlin, Germany.

[14] Kabala, C., Singh, B.R. (2001): Fractionation and mobility of cooper, lead, and zinc in soil profiles in the vicinity of a copper smelter. - J. Environ. Qual. 30: 485-492.

[15] Kahler, H. (1993) Response of roots of trees to heavy metals. - Environmental and Experimental Botany 33:99.

[16] Koch, M., Rotard, W. (2001): On the contribution of back-ground source to heavy metal content of municipal sewage-sludge. - Water Sci. Technol. 43: 67-74.

[17] KrishnaRaj, S., Dan, T.V., Saxena, P.K. (2000): A fragrant solution to soil remediation. Int. J. Phytorem. 2: 117-132.

[18] Kumar, N., Bauddh, K., Kumar, S., Dwivedi, N., Singh, D.P., Barman, S.C. (2013): Extractability and phytotocity of heavy metals present in petrochemical industry sludge. Clean Techn. Environ. Policy 15: 1033-1039.

[19] Lai, W.J., Xu, B., He, L., Lin, M., Cao, L., Wu, Y., Mou, S., He, S. (2012): Cadmium uptake by and translocation within rice (Oryza sativa L.) seedlings as affected by iron plaque and $\mathrm{Fe}_{2} \mathrm{O}_{3}$. - Pakistan J. Bot. 44: 1557-1561.

[20] Lavado, R.S., Bodŕiguez, M.B., Scheiner, J.D., Taboada, M.A., Rubio, G., Alvarez, R., Alconada, M., Zubillag,a M.S. (1998): Heavy metals in soils of Argentina: Comparison between urban and agricultural soils. - Comm. Soil Sci. Plant Anal. 29: 1913-1917. 
[21] Lee, J.S., Jeong, S.J., Heo, J.A., Kang, H.J., Hwang, S.Y., Kim, Y.K. (2002): Light intensity levels and growth inhibitors on growth of shade tolerant Japanese spurge (Pachysandra terminalis). - J. Kor. Soc. Hort. Sci. 43: 137-142.

[22] Li, Y.M., Chaney, R.L., Siebielec, G., Kerschner, B.A. (2000): Response of four turfgrass cultivars to limestone and biosolids-compost amendment of a zinc and cadmium contaminated soil at Palerton, Pennsylvania. - J. Environ. Qual. 29: 1440-1447.

[23] Mahnaz, K., Shabnam, P., Behnaz, F., Abbas, H., Seyed, N.O. (2010): Cytotoxicity of Vinca minor. - Pharmaceut. Biol. 48: 96-100.

[24] Maksymiec, W. (2007): Signaling responses in plants to heavy metal stress. - Acta Physiol. Plant 29: 177-187.

[25] Marchiol, L., Assolari, S., Sacco, P., Zerbi, G. (2004): Phytoextraction of heavy metals by canola (Brassica napus) and radish (Raphanus sativus) grown on multicontaminated soil. - Environ. Pollution 132: 21-27.

[26] Marschner, H. (1995): Mineral nutrition of higher plants, 2nd ed. - Academic Press, London, UK.

[27] Naz, A., Khan, S., Muhammad, S., Khalid, S., Alam, S., Siddique, S., Ahmed, T., Scholz, M. (2015): Toxicity and bioaccumulation of heavy metals in spinach (Spinacia oleracea) grown in a controlled environment. - Int. J. Environ. Res. Public Health 12: 7400-7416.

[28] Orroño, D., Benítez, H., Lavado, R.S. (2009): Effects of heavy metals in soil on biomass production and plant element accumulation of Pelargonium and Chrysanthemum species. - Agrochemica 53: 168-176.

[29] Pahlsson, A.M.B. (1989): Toxicity of heavy metals ( $\mathrm{Zn}, \mathrm{Cu}, \mathrm{Cd}$ and $\mathrm{Pb}$ ) to vascular plants. - Water Air Soil Poll. 47: 287-319.

[30] Qu, R.L., Li, D., Du, R., Qu, R. (2003): Lead uptake by root of four turfgrass species in hydroponic cultures. - HortScience 38: 623-626.

[31] Qureshi, M.I., Qadir, S., Zolla, L. (2007): Proteomics-based dissection of stressresponsive pathways in plants. - J. Plant Physiol. 164: 1239-1260.

[32] Tian, R.N., Yu, S., Wang, S.G., Zhang, Y., Tang, J.Y., Liu, Y.L., Nie, Y.H. (2013): Heavy metal tolerance and accumulation of Triarrhena sacchariflora, a large amphibious ornamental grass. - Water Science \& Technology 68(8): 1795-1800.

[33] Vesna, G.C., Vera, R., Milorad, V., Mara, T.T., Dragica, V. (2012): Influence of heavy metals on seed germination and growth of Picea abies L. - Karst. Pol. J. Environ. Stud. 21: 355-361.

[34] Ward, N.I. (1995): Environmental analytical chemistry. p. 320-328. - In: Fifield, F.W., Haines, P.J. (eds.) Trace elements. Blackie Academic and Professional. London, UK.

[35] Wang, Z., Zang, Y., Huang, Z., Huang, L. (2008): Antioxidative response of metalaccumulator and non-accumulator plants under cadmium stress. - Plant Soil 310: 137149.

[36] Xu, J., Zhang, Y.X., Wei, W., Han, L., Guan, Z.Q., Wang, Z., Chai, T.Y. (2008): BjDHNs confer heavy-metal tolerance in plants. - Mol. Biotechnol. 38: 91-98.

[37] Yang, X.E., Long, X.X., Ni, W.Z., Ye, Z.Q., He, Z.L., Stoffella, P.J., Calvert, D.V. (2002): Assessing copper thresholds for phytotoxicity and potential dietary toxicity in selected vegetables crops. - J. Environ. Sci. Health 37: 625-635.

[38] Yoon, J., Cao, X., Zhou, Q., Ma, L.Q. (2006): Accumulation of Pb, $\mathrm{Cu}$ and $\mathrm{Zn}$ in native plants growing on a contaminated Florida site. - Sci. Total Environ. 368: 456-464.

[39] Zeliha, L., Ahmet, A., Fatih, D. (2011): Influence of salinity on the growth and heavy metal accumulation capacity of Spirodela polyrrhiza (Lemnaceae). - Turkish Journal of Biology 35: 215-220.

[40] Zhang, S., Zhang, H., Qin, R., Jiang, W., Liu, D. (2009): Cadmium induction of lipid peroxidation and effects on root tip cells and antioxidant enzyme activities in Vicia faba L. - Ecotoxicology 18: 814-823. 
[41] Zhihua, J., Jianhua, L. (2009): Phylogenetics and biogeography of eastern Asian-North American disjunct genus Pachysandra (Buxaceae) inferred from nucleotide sequences. Int. J. Syst. Evol. 47: 191-201.

[42] Zhou, S.P., Sauve, R.J., Mmbaga, M.T. (2005): Adaptation of Pachysandra terminalis Sieb. \& Zucc. to freezing temperatures by the accumulation of mRNA and cold-induced proteins. - HortScience 40: 346-347.

[43] Zhu, J.J., Beck, E. (1991): Water relations of Pachysandra leaves during freezing and thawing. - Plant Physiol. 97: 1146-1153.

[44] Zu, Y., Ki, Y., Christian, S., Laurent, L., Fan, L. (2004): Accumulation of Pb, Cd, Cu and $\mathrm{Zn}$ in plants and hyperaccumulator choice in Lanping lead-zinc mine area, China. Environ. Int. 30: 567-576. 